Висновки. Отримані результати віддзеркалюють загальну картину результатів впровадження кредитно-модульної системи в порівнянні $з$ традиційною. Незважаючи на недосконалі шляхи впровадження нової системи, з часом відбувається складний процес оптимізаціїта коадаптаціїнаціональних та європейських модульних технологій навчання. Крок за кроком поступово удосконалюються шляхи реформування вищої

\section{Література}

1. Визначення критеріїв якості в системі безперервного професійного розвитку лікарів та провізорів на основі концепції кредитів / Ю. В. Вороненко, А. М. Сердюк [та ін.]// Медична освіта. -2007. - №3.-С.11-15.

2. Комюніке Конференції міністрів європейських країн, відповідальних за сферу вищої освіти (Лондон, 16-19 травня 2007 року). -К.,2008. - Кн. 4 : Основні засади розвитку вищої освіти України. - С. 24-30.

3. Байденко В.И. Болонский процесс : структурная реформа высшего образования Европы / В. И. Байденко. [3-е изд-е]. - М. : Исследовательский центр проблем каче- медичної освіти в України згідноз європейськими стандартами. Кожна країна, реформуючи свою освіту, має повнеправо враховувати специфіку як свосї національної системи освіти, так і медичної освіти в цілому. Важливо, щоб процес подальшої інтеграції вітчизняної і європейської систем підготовки лікарів здійснювався шляхом зближення гармонійного поєднання вітчизняного і міжнародного досвіду.

ства подготовки специалистов, Российский Новый Университет, 2003. - С. 28-30.

4. Болонский процесс : нарастающая динамика и многообразие (документы международных форумов и мнения европейских экспертов). - М. : Исследовательский центр проблем качества подготовки специалистов, 2002. - С. 231-234.

5. Вища медична освіта і Болонський процес : Навч.-метод. та інф.-довідк. матеріали наради-семінару для науково-педагогічних працівників, аспірантів, магістрів (17-19 січня 2005 р.). - Київ, 2005. - Ч. І.-С. 81-84.

УДК 378:377.35:615

\title{
ФОРМУВАННЯ ПРОФЕСІЙНОЇ КОМПЕТЕНТНОСТІ МАЙБУТНЬОГО ФАРМАЦЕВТА В УМОВАХ КРЕДИТНО-МОДУЛЬНОЇ СИСТЕМИ ОСВІТИ
}

\author{
В. Ф. Москаленко, І. В. Ніженковська, О. В. Вельчинська \\ Начіональний медичний університет імені О. О. Богомольия
}

\begin{abstract}
FORMATION OF THE PROFESSIONAL COMPETENTCE OF THE FUTURE PHARMACIST IN CONDITIONS OF CREDIT-MODULAR EDUCATIONAL SYSTEM
\end{abstract}

\author{
V. F. Moskalenko, I. V. Nizhenkovska, O. V. Velchynska \\ National Medical University by O. O. Bohomolets
}

\begin{abstract}
Для покращення якості підготовки студентів фармацевтичного факультету Національного медичного університету імені О. О. Богомольц необхідно акцентувати увагу на формуванні професійної компетентності майбутніх фармацевтів. Компетентність у професійній підготовці фармацевта розглядається як інтегрована характеристика особистості фахівця. Вона включас здатність гідно виконувати свої професійні функції, кваліфіковано забезпечувати населення необхідними лікарськими засобами. Для того щоб реалізувати зазначені цілі, майбутньому фармацевтові необхідно мати високий рівень теоретико-методологічних знань гуманітарних та соціально-економічних, фундаментальних та фармацевтичних дисциплін. Необхідними рисами майбутнього професіонала повинні стати наявність бажання до поглибленого вивчення фахових дисциплін та прагнення до творчості в професійній діяльності. Важливу роль відіграють: наявність особистісних досягнень, бажання до самопізнання, прагнення професійного росту, формування індивідуального стилю роботи. Професійна підготовка майбутнього фармацевта базується на формуванні не тільки його фахових характеристик,
\end{abstract}

(c) В. Ф. Москаленко, І. В. Ніженковська, О. В. Вельчинська 
а й особистісних якостей фахівця. Від рівня професійної компетентності повністю залежить працевлаштування випускників. До найбільш важливих професійних компетенцій фармацевтів можна віднести: знання, вміння і навички 3 професійної діяльності; комунікативні вміння і навички, здатність спілкуватися та консультувати відвідувачів аптечних закладів.

To improve the quality of students' training of pharmaceutical faculty of O. O. Bohomolets National Medical University it is necessary to accent attention on the formation of the professional competence of the future pharmacists. Competence at the professional training of pharmacist is viewed as integral characteristic of the professional person. It's including the ability to carry out own professional functions worthy, to provide the population by necessary medical products qualified. Future pharmacist must have a high level of the theoretical-methodological knowledge of humanities and social-economical, fundamental and pharmaceutical disciplines for realization of the purposes. Presence of the wish of more deep study of the special disciplines and aspiration to creative work at the professional activity must be necessary lines of the future professional. Presence of own achievements, desire of self-perception, aspiration to professional growth, formation of individual style of the work are playing an important role.

Professional training of the future pharmacist is based not only on the formation of his special characteristics but on his personal qualities. Get a job of the graduates depends on their level of the professional competence.

The most important professional competentces are: knowledges, abilities and experiences of the professional activity; communication's abilities and experiences, ability to relations and consultations with visitors of drugstores.

Вступ. Одним із найважливіших завдань діяльності Національного медичного університету іменіО. О. Богомольця як вищого навчального закладу є якісна професійна підготовка студентів фармацевтичного факультету-майбутніх фармацевтів, комплексний вплив на їх свідомість і поведінку, результатом чого повинно бути засвоєння знань, умінь та практичних навичок, визначених стандартами вищої освіти. У зв' язку із становленням фармацевтичного ринку, наявністю суперечностей між професійними вимогами, які висуваються до провізора, і сучасними умовами розвитку фармацевтичного ринку, проблема якісної професійної підготовки майбутніх фармацевтів, формування їх професійної компетентності в умовах сьогодення набуває особливої актуальності.

Основна частина. Компетентність у професійній підготовці фармацевта може бути реалізована при наявності особистих компетенцій майбутнього фахівця, від чого буде залежати його здатність виконувати певні професійні функції щодо кваліфікованого забезпечення населення лікарськими засобами. Важливу роль відіграє особистісний компонент, який формується на основі наявності у майбутнього фармацевта мотивів і потреби працювати, особистих прагнень і завдань, зацікавленості поглибленим вивченням фахових дисциплін; прагнення до творчості в професійній діяльності, об'єктивності, самокритичності в оцінці досягнутого рівня розвитку власної професійної компетентності. При цьому система набутих теоретико-методологічних знань з гуманітарних та соціально-економічних, фундаментальних і фармацевтичних дисциплін вкрай необхідна для забезпечення професійної діяльності та спілкування. Для успішної професійної діяльності обов' язковим залишається набуття професійних умінь, визначених у галузевому стандарті підготовки провізора. Фармацевтичний сектор України перебуває на етапі становлення, тому основні принципи законодавства країн
СС в галузі ліцензування та контролю за лікарськими засобами мають особливу актуальність для України. Досвіду країн СС у розробці законів у фармацевтичній галузі більше ніж 30 років. Використання принципів ЄС у практиці державного регулювання фармацевтичного сектора сприятиме прискореннюінтеграції України до європейського ринку, підвищенню конкурентоспроможності та якості українських лікарських засобів. Тому так важливо постійно ознайомлювати студентів 3 основними стандартами фармацевтичної галузі: GMP, GLP, GCP. Вони повинні розуміти значущість тих змін, які відбуваються як на світовому, так і на українському фармацевтичних ринках.

Разом із тим, особливою складовою підготовки майбутніх фармацевтів є набуття комунікативних умінь, які передбачають здатність розуміти взаємини людей, адекватно сприймати ситуацію спілкування, адаптивність і комунікабельність. Для професійної фармацевтичної діяльності необхідно навчати студентів творчого підходу у вирішенні конкретних завдань організаційного, пошукового, аналітичного, комунікативного характеру; розвивати в них здатність до самоосвіти й самовдосконалення. Налаштованість на співпрацю та критичне прогнозування результатів діяльності й відносин допоможуть майбутнім фармацевтам гідно виконувати свою роботу. Необхідно розвивати у студентів здатність застосовувати знання i вміння, бажання до самопізнання, прагнення професійного росту, формування індивідуального стилю роботи. Це буде впливати на рівень розвитку самооцінки, розуміння власної значущості для інших людей, відповідальності за результати своєї діяльності, реалізацію в процесі професійної діяльності.

Висновок. Таким чином, у професійній підготовці фармацевта існують проблеми оцінки фахових й особистісних якостей фахівця. Настав час, коли необхідно переглянути функції та вимоги до фармацевта. Немало відвідувачів аптеки звертається до фарма- 